\title{
EARLY MODELS DESCRIBING THE FIRE INSURANCE RISK *
}

\author{
Paul Johansen
}

1. It has been known for generations that the fire risk rate increases with the size of the insured object in a similar way as the death rate increases with the age.

Professor d'Addario and other Italian mathematicians have shown that statistical data often can be graduated by the formulas where $S$ denotes the sum insured:
risk of outbreak of fire
const. $S^{\alpha}$
average loss
const. $S^{-\beta}$
risk premium rate
const. $S^{\alpha-\beta}$

In 1940, d'Addario') in a practical case found the values $\alpha=0.78, \beta=0.44$. In 1956, Blandin and Depoid have used the same formulas. Although these formulas in practical cases often lead to good approximations, one can hardly say that a proper mathematical or physical model describing the behaviour of fires lies behind.

2. About 1950, I worked with the statistics of a group of Danish fire insurance companies, in particular covering farm buildings. This investigation was organized by (sunnar Benktander. Our data confirmed the increase of the fire risk rate with the size of the buildings.

In one special group: Farm houses with thatched roofs, this increase was so important that the risk premium was approximately proportionate to the square of the sum insured. The statistics fully justified the tariffing and we tried to construct a model describing and explaining the observed facts.

The risk group in question was characterized by the overwhelming importance of total or practically total losses. Only a few per cent of the damages went to minor fires. When a fire breaks out in such a building, and reaches a certain slight extent, then it is not possible to save the building from total destruction. With sufficient approximation, we may say that only total losses occur (as in life assurance).

The risk that a fire breaks out will depend on the number of risk situations. In the type of buildings in question, the number of risk situations-chimneys, cookers, bedrooms, electric equipment -was approximately proportionate to the size and to the sum insured of the house. In this case, the risk premium is proportionate to the square of the sum insured.

*) P'resented at the $14^{\text {th }}$ ASTIN Colloquium, Taormina, October 1978.

1 Annali dell' Istituto di Statistica, Vol. 17, Bari, 1940. 
This very special result which was presented to the 1957 New York Congress, could fit into the general d'Addario formula. I had simply found the extreme values $\alpha=1$ and $\beta=0$.

3. It is needless to say that I thought to be first in describing the extreme situation in question. Quite recently, however, I found that it was contained in an old paper in the 1907 volume of Zeitschrift fiur die gesamte Versicherungswissenschaft, pp. 226-243, by a Russian Government officer, dr. Sergius von Sawitsch. The title in translation: The influence of the dimensions of a fire risk on the premium rate.

As far as von Sawitsch knows, no attempt had at that time been made to study the variation of the fire risk with the size of the insured object. In order to construct a fair tariffing principle, he studies a homogeneous three-dimensional risk field with equal risk of outbreak of a fire in each point and with equal risk of propagation in all directions. This indicates that the risk of spreading of a fire from one point of the field to another depends on the distance between the two points only. Mathematically, this means that the propagation risk is $q^{r}$ where $q$ is a constant and $r$ the distance. When you integrate this expression over the whole field, you find a factor expressing the aggregate propagation risk within the field. If $q=0$, there is no propagation risk and in the case of extremely inflammable goods when $q=1$, you find the propagation factor equal to the size of the field. In fact, this is the very same situation which I described $5^{\circ}$ years later.

Von Sawitsch in detail studies the one-dimensional question of vertical propagation of a multi-floored house. This propagation is regarded as discontinuous. In some numerical examples he assumes the probability of spreading of a fire from one floor to the next above or below to be either $1 / 2$ or $1 / 10$. Under these conditions, he gives a table of the relative risk premiums of the individual flats of a five- or eight-floored house. By the way, the hypothesis that a fire will spread with equal probability upwards and downwards does not seem likely. One would normally think that the propagation upwards will be stronger. A chimney sweeper, however, has shown me that when lighting an open fire, one should put the big firewood in the bottom, then kindlings and paper on the top. That never fails!

In some detail he also studies the two-dimensional case and he gives expressions of the relative risk in various points of the field and of the correlation between the size of the field and its total risk. He even attacks the more complicated question of fire propagation between two separate buildings.

Finally, von Sawitsch promises to return to the question of estimating the parameters in his models. As far as I know, he has never fulfilled that promise.

4. Thinking that he was the first to describe the fire risk by mathematical 
models, von Sawitsch was wrong. The first attempt to do so dates more than 80 years further back, and it was by mere chance that I found it recently.

In the 1835 proceedings of the Société Royale des Sciences, de l'Agriculture et des Arts de Lille (France), Théodore Joseph Barrois has published a 200 pages paper, presented to that society on July 22,1834 . Its title in translation: On the application of probability theory on fire insurance.

Very little has been known among actuaries of Barrois and his works. In 1892 his paper was introduced to the Institut des Actuaires Français by P. Soulier, but also this review drew little or no attention.

Th. Barrois, who lived from 1793 to 1851 was an industrialist. He was keen on mathematics and mechanics and held many patents for improvements of the machines used in his factories. One of his inventions was the safety valve preventing explosions of steam engines.

Apart from the paper mentioned above, he has written articles on pneumatic and other boat motors. He was elected membre résidant of the Société Royale in 1825. It is not known whether he had any special relations to one of the newly founded French fire insurance companies.

5. Barrois' paper is difficult to read today. The language and the mathematical methods are far from what we use now. The fundamental ideas, however, and the mathematical models are here.

"Since the year 1815-says Barrois-several fire insurance companies have been founded in France. These useful institutions, however, leave much to be desired regarding a proper valuation of the assured risks." An actuary today could sign these words.

Another citation: "We have also seen the introduction of several kinds of assurance on human life. Some famous geometers have made important studies on these subjects, the results of which have been used by tontines and life assurance companies. These institutions are the only who know the risk, against which they insure. We think that also fire insurance should use calculus."

The model of Barrois is of dimension one. The fire can only propagate in one direction, continuously like in a fuse or discontinuously, like jumping from one house in a row to the neighbours. He reaches practically the same results, for instance regarding the differentiation of risk on the various floors of a house, as did von Sawitsch much later.

Barrois' model in the discontinuous case is composed by a series of risk units or cells, each cell has one floor and an extent of 10 meters square. After some discussion, he supposes that the propagation risk is constant; the probability that the fire jumps from one cell to its neighbours in the chain does not depend on the history of the fire. One can say that he deals with Markovian chains.

If the propagation probability for a chain with this unity of dimension 1 is $a$, 
he proves that the corresponding probability for a chain with dimension $D$ is

$$
b=a D /(1-a+a D)
$$

"In the special case -he says-where it is certain that a fire once broken out will destroy the whole chain, then the assurance will grow proportionate to the sum assured and to the volume of the building. So the premium must increase with the square of the building or of the sum assured."

He also demonstrates, that in a row of houses, attached to each other, the owner of the house in the middle must pay a higher premium than the owners of the houses at the ends. In practice, such distinction is hardly practicable.

6. Barrois divided the fire risk into two elements, the outbreak risk and the propagation risk: "The fire risk varies with the size of the houses, their number of floors, the arrangement and use, the caution of the inmates and the state of fire protection. All these elements, of which depends the insurance premium can be reduced to the probability that a fire breaks out and of its propagation from one point to another. These two elements are essentially distinct and must necessarily enter into the assessment of the premium."

He supposes that the probalility of fire in a certain object is constant. This assumption is very characteristic for his time. He says that the basic law is quite like the probability scheme regulating the drawing of red and black balls from an urn. He bases his assumption on the fact that the underlying causes for a fire are the human imprudence and wickedness while preventing causes are a general desire for protection and the fear of fire.

"History shows us that man at all times is motivated by the same passions and never changes. He has the same carelessness, the same imprudence, the same wickedness and the same fear of fire as ever. Therefore the outbreak of fires will follow a permanent law when the circumstances are the same."

I think that this statement is typical for his time. It is like Süssmilch who believed in a Divine Order with for example invariable death rates.

On the other hand, Barrois thought that "the probability of fire is not necessarily the same for the insured houses as for the others. The owners who are insured against fire losses will become more negligent. But, on the other hand, if there were an incendiary who would revenge himself on an enemy by putting fire on his house, he would not have the same strong motives, if the house were insured."

7. It is a great pity that Barrois' work has never been generally known. ${ }^{2}$ ) I am sure that if the actuaries of my generation had known his paper, the research would have advanced further and the fire insurance premiums would have been more equitable. His models are close to those of von Sawitsch and

${ }^{2}$ Hilary Seal in Survival Probabilities (Wiley 1978), shortly mentions Barrois' work. 
a further study will lead to formulas of the same type as d'Addario's formulas mentioned above.

I hope that some young actuaries could find inspiration to a group work together with engineers and underwriters. No doubt, this could lead to good results, even if the work has been delayed by a century and a half.

Should this work result in a model applicable to modern fire insurance, I would find it reasonable to name it Barrois' model. In the insurance mathematics, the name Barrois deserves a place of honour besides that of Makeham. 